\title{
Periostin loss-of-function protects mice from post-traumatic and age-related osteoarthritis
}

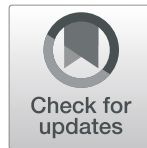

Mukundan Attur ${ }^{1 * \dagger}$, Xin Duan ${ }^{2 \dagger}$, Lei Cai ${ }^{2}$, Tianzhen Han ${ }^{1,3}$, Weili Zhang ${ }^{2}$, Eric D. Tycksen ${ }^{4}$, Jonathan Samuels ${ }^{1}$, Robert H. Brophy ${ }^{2}$, Steven B. Abramson ${ }^{1}$ and Muhammad Faroog Rai ${ }^{2,5^{*}}$ (D)

\begin{abstract}
Background: Elevated levels of periostin (Postn) in the cartilage and bone are associated with osteoarthritis (OA). However, it remains unknown whether Postn loss-of-function can delay or prevent the development of OA. In this study, we sought to better understand the role of Postn in OA development and assessed the functional impact of Postn deficiency on post-traumatic and age-related OA in mice.

Methods: The effects of Postn deficiency were studied in two murine experimental OA models using Post ${ }^{-/-}(n=$ 32) and littermate wild-type $(w t)$ mice $(n=36)$. Post-traumatic OA was induced by destabilization of the medial meniscus (DMM) in 10-week-old mice ( $n=20)$; age-related OA was analyzed in 24-month-old mice $(n=13)$. Cartilage degeneration was assessed histologically using the OARSI scoring system, and synovitis was evaluated by measuring the synovial lining cell layer and the cells density in the synovial stroma. Bone changes were measured by $\mu C T$ analysis. Serum levels of Postn were determined by ELISA. Expression of Postn and collagenase-3 (MMP-13) was measured by immunostaining. RNA-seq was performed on chondrocytes isolated from 21-day old Postn ${ }^{-1-}$ $(n=3)$ and $w t$ mice $(n=3)$ to discover genes and pathways altered by Postn knockout.
\end{abstract}

Results: Postn ${ }^{-1-}$ mice exhibited significantly reduced cartilage degeneration and OARSI score relative to wt mice in post-traumatic OA after 8 weeks (maximum: $2.37 \pm 0.74$ vs. $4.00 \pm 1.20, P=0.011$; summed: $9.31 \pm 2.52$ vs. $21.44 \pm$ $6.01, P=0.0002$ ) and spontaneous $\mathrm{OA}$ (maximum: $1.93 \pm 0.45$ vs. $3.58 \pm 1.16, P=0.014$; summed: $6.14 \pm 1.57$ vs. $11.50 \pm 3.02, P=0.003)$. Synovitis was significantly lower in Postn ${ }^{-1-}$ mice than wt only in the DMM model $(1.88 \pm$ 1.01 vs. $3.17 \pm 0.63 ; P=0.039$ ). Pos $t^{-1-}$ mice also showed lower trabecular bone parameters such as BV/TV, $v B M D$, Tb.Th, and Tb.N and high Tb. Sp in both models. Postn ${ }^{-1-}$ mice had negligible levels of serum Postn compared with wt. Immunofluorescent studies of cartilage indicated that Post ${ }^{-1-}$ mice expressed lower MMP-13 levels than wt mice. RNA-seq revealed that cell-cell-adhesion and cell-differentiation processes were enriched in Postn ${ }^{-1}$ mice, while those related to cell-cycle and DNA-repair were enriched in wt mice.

(Continued on next page)

\footnotetext{
*Correspondence: mukundan.attur@nyulangone.org; rai.m@wustl.edu

${ }^{\dagger}$ Mukundan Attur and Xin Duan contributed equally to this work.

'Division of Rheumatology, Department of Medicine, New York University

Grossman School of Medicine, Langone Orthopedic Hospital, 550 1st

Avenue, New York, NY 10016, USA

${ }^{2}$ Department of Orthopaedic Surgery, Washington University School of

Medicine at Barnes-Jewish Hospital MS 8233, 425 South Euclid Avenue, St.

Louis, MO 63110, USA

Full list of author information is available at the end of the article
}

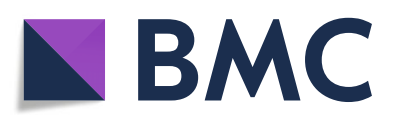

(- The Author(s). 2021 Open Access This article is licensed under a Creative Commons Attribution 4.0 International License, which permits use, sharing, adaptation, distribution and reproduction in any medium or format, as long as you give appropriate credit to the original author(s) and the source, provide a link to the Creative Commons licence, and indicate if changes were made. The images or other third party material in this article are included in the article's Creative Commons licence, unless indicated otherwise in a credit line to the material. If material is not included in the article's Creative Commons licence and your intended use is not permitted by statutory regulation or exceeds the permitted use, you will need to obtain permission directly from the copyright holder. To view a copy of this licence, visit http://creativecommons.org/licenses/by/4.0/. The Creative Commons Public Domain Dedication waiver (http://creativecommons.org/publicdomain/zero/1.0/) applies to the data made available in this article, unless otherwise stated in a credit line to the data. 
(Continued from previous page)

Conclusions: Postn deficiency protects against DMM-induced post-traumatic and age-related spontaneous OA. RNA-seq findings warrant further investigations to better understand the mechanistic role of Postn and its potential as a therapeutic target in OA.

Keywords: Periostin, Knee osteoarthritis, Trauma, Aging, MMP-13, RNA-seq

\section{Introduction}

Osteoarthritis (OA) is a clinical syndrome that affects more than 50 million people in the USA, with $\$ 185$ billion in annual socioeconomic costs [1, 2]. Currently, there are no proven treatments to delay, let alone prevent, the progression of OA. Thus, a treatment that slows or halts disease progression before end-stage joint failure and arthroplasty is sorely needed. OA is recognized as a whole joint disease that affects all tissues (bone, cartilage, synovium, meniscus, and ligaments) [3, 4], although cartilage degeneration is considered the hallmark of end-stage disease [5]. Despite advances in preclinical studies, the pathways controlling early cartilage degeneration and new bone formation in OA remain unknown. Therefore, a critical issue in OA treatment is discovering early OA mediators, particularly elucidating the underlying intracellular signal transduction pathways, which affects multiple tissues in the joints.

Emerging evidence indicates periostin (Postn) is upregulated in patients with OA [6-9] and has been identified as a gene of interest in articular cartilage [10-12]. Postn is a vitamin K-dependent and glutamatecontaining matricellular protein [13]. Postn, a member of the fasciclin family of proteins, was originally called osteoblast-specific factor 2 [14]. First identified in murine osteoblasts, it is also found in the periosteum [15]. Postn plays key roles in health and disease across various disciplines such as osteology and oncology [16-20]. It also plays a role in the repair mechanism of many connective tissues and organs such as the periodontal tissue, heart, and lungs [15, 16, 20-23]. Postn is considered important for its role in maintaining tissue integrity. In the bone, Postn is predominantly expressed in the periosteum and considered a key extracellular matrix (ECM) protein needed in health and healing. For instance, loss of Postn influences the propensity to fatigue fractures in mice [24], and Postn-deficient periosteum cannot reconstitute stem cells after injury [25]. Despite this evidence for the importance of Postn, it also has an adverse role in various inflammatory settings [26-28].

We have shown that expression of Postn is induced following joint trauma such as destabilization of the medial meniscus (DMM) or anterior cruciate ligament transection/partial medial meniscectomy and leads to development and progression of OA [12, 22]. Recently, our data confirmed that the Postn expression increases significantly in mouse and human cartilage and osteophytes during $\mathrm{OA}$ progression. Immune-localization studies further revealed that Postn was present in the cartilage ECM [10, 12, 22]. Emerging evidence supports the involvement of Postn in Wnt signaling activation and MMP-13 expression. Postn-induced MMP-13 expression was also inhibited by CCT031374 hydrobromide, an inhibitor of the canonical Wnt/ $\beta$-catenin signaling pathway [12]. These findings suggest a catabolic role for Postn in promoting cartilage degeneration in OA by upregulating MMP-13 in response to injury.

In the present study, we hypothesize that genetic Postn loss-of-function in mice would protect against cartilage degeneration, synovitis, and bone changes secondary to aging and knee injury. To test this hypothesis, we assessed cartilage degeneration, synovial pathology, and bone morphometric parameters in two animal models. One consisting of 24-month-old mice with spontaneous $\mathrm{OA}$ and one with surgically induced OA model in 10week-old mice. Postn knockout mice were compared to wild-type $(w t)$ in both cohorts. We also performed RNA-seq on chondrocytes isolated from both Postn ${ }^{-1-}$ and $w t$ mice in a pursuit to identify genes and pathways altered following Postn knockout.

\section{Methods}

\section{Animals}

In this study, we used homozygous mutant Postn $^{\text {tm1Jmol } / \mathrm{J}}$ (Postn $^{-/-}$; Stock No. 009067) mice on a B6129SF2/J (wt; Stock No. 101045) background. Postn ${ }^{-/-}$and $w t$ mice were obtained from The Jackson Laboratories (Bar Harbor, ME). Post-traumatic OA studies were performed at Washington University (St. Louis, MO), and aging studies were conducted at New York University Grossman School of Medicine (New York, NY). Postn ${ }^{-\prime-}$ mice were obtained by crossing heterozygous mice, and littermate mice from the same breeding were used for all experiments. All mice were kept and bred at the study institutions and genotyped by polymerase chain reaction (PCR) using tail deoxyribonucleic acid separated on $1.5 \%$ agarose gel using standard methods. Mice were housed in individually ventilated cages, with each cage having no more than five mice at a time in a hygienic barrier facility operating at $21-22^{\circ} \mathrm{C}$. Food and water were available ad libitum, and animals were maintained in a 12-h light, 12 -h dark cycle. We used only male mice given sex 
differences in the DMM model [29]. The number of mice in each experimental group and each genotype are indicated in figure legends and summarized in Table 1.

\section{Detection of Postn protein in the murine serum}

Postn deficiency in Postn ${ }^{-/-}$mice was detected by solidphase enzyme-linked immunosorbent assay (ELISA). Briefly, mice euthanized by carbon dioxide asphyxiation were exsanguinated by cardiac puncture using minicollect serum separator tubes (Greiner Bio-One, Monroe, NC). The blood was allowed to clot at room temperature for $30 \mathrm{~min}$ and retract at $4{ }^{\circ} \mathrm{C}$ for $4 \mathrm{~h}$. The clotted blood was centrifuged at $2500 \mathrm{rpm}$ at $4{ }^{\circ} \mathrm{C}$ for 10 min. The serum was collected, centrifuged, and stored at $-20^{\circ} \mathrm{C}$ until used. Postn concentration in serum was measured using a mouse periostin/OSF-2 Quantikine ELISA kit according to the manufacturer's instructions (MOSF20, R\&D Systems Inc., Minneapolis, MN). In brief, $50 \mu \mathrm{l}$ assay diluent was added to each well of a 96well strip plate followed by an equal volume of standard, control, and sample in individual wells. The plate was incubated at room temperature on a horizontal orbital microplate shaker. After $2 \mathrm{~h}$ of incubation, the contents were removed, and each well was washed five times with the supplied wash buffer. Subsequently, $100 \mu$ l conjugate was added to each well followed by 2 -h incubation at room temperature with constant shaking. Then, following washing as above, the plate was incubated with $100 \mu \mathrm{l}$ substrate solution in each well for $30 \mathrm{~min}$. Finally, the reaction was terminated with the addition of $100 \mu \mathrm{l}$ of stop solution and the plate was read at $450 \mathrm{~nm}$ within $30 \mathrm{~min}$.

\section{Induction of post-traumatic $O A$}

To determine the role of Postn loss-of-function in posttraumatic OA, we performed the DMM surgery on 10week-old male Postn ${ }^{-1-}$ or $w t$ mice as described [30]. In short, mice were anesthetized with $2.5 \%$ isoflurane in $4 \mathrm{~L} / \mathrm{min}$ oxygen. After aseptic preparation of the right

Table 1 Distribution of mice for each experiment

\begin{tabular}{llll}
\hline Genotype & Age & Experiment & $\boldsymbol{n}$ \\
\hline Postn $^{-1-}$ & 10 weeks & DMM & 10 \\
& 24 months & Aging & 7 \\
24 months & Serum & 6 \\
21 days & RNA-seq & 3 \\
& 21 days & Real-time PCR & 6 \\
$w t$ & 10 weeks & DMM & 10 \\
& 24 months & Aging & 6 \\
& 24 months & Serum & 11 \\
& 21 days & RNA-seq & 3 \\
& 21 days & Real-time PCR & 6 \\
\hline
\end{tabular}

hind limb, the joint capsule immediately medial to the patellar tendon was cut open, and the anterior attachment of the medial meniscotibial ligament was severed with sterilized microsurgical tools. This step resulted in the destabilization of the medial meniscus. Afterward, the joint capsule was closed with 6-0 absorbable polypropylene sutures (Ethicon, Blue Ash, $\mathrm{OH}$ ), and the skin was closed by Vetclose skin glue (Henry Schein, Melville, $\mathrm{NY}$ ). However, we used the contralateral left hind limb as non-operated control to avoid the effect of surgery. In compliance with guidelines, sustained-release buprenorphine $(1.0 \mathrm{mg} / \mathrm{kg})$ was administered once as an analgesic before surgery. No other pain-relieving medication was given to the mice. All mice were weight-bearing following recovery from the general anesthesia and resumed previous cage activity, water consumption, and food intake. Mice were euthanized 8 weeks after surgery by carbon dioxide inhalation. Hind limbs were separated, skinned, and subjected to histological and micro-computed tomography $(\mu \mathrm{CT})$ analyses.

\section{Age associated spontaneous OA}

For aging studies, 24-month-old wt and Postn ${ }^{-1-}$ mice were sacrificed using carbon dioxide asphyxiation; the hind limbs were separated, skinned, and prepared for histological and $\mu \mathrm{CT}$ analyses.

Histological assessment of cartilage degeneration and $O A$ The knee joints were fixed in $10 \%$ neutral-buffered formalin for $48 \mathrm{~h}$ and decalcified using $12 \%$ formic acid, then embedded in paraffin using standard methods. Twelve coronal sections, each with $5 \mu \mathrm{m}$ thickness, were taken from each joint at eight levels separated by $80 \mu \mathrm{m}$ intervals. From each level, three sections were stained with Safranin O [31]. In each genotype, the same number and depth of sections were evaluated. The semiquantitative Osteoarthritis Research Society International (OARSI) scoring system (scale: 0-6) was used to assess cartilage damage [32]. Cartilage damage was measured and scored in all four tibiofemoral compartments of the knee (lateral and medial femoral condyles and lateral and medial tibial plateaus) at all sectioned levels. The maximum OARSI score representing the highest score within all sectioned levels of the knee was recorded. Summed OARSI score was calculated by adding the total scores of four consecutive levels of each knee. Two independent scorers blinded to genotype and procedure scored the sections with a high inter-rater reliability.

\section{Histological assessment of synovitis}

Safranin O-stained sections were graded for synovitis in the medial compartment for two parameters using a method developed by Lewis and colleagues [33]. 
Enlargement of the synovial lining cell layer is measured on a scale of $0-3$, separately from the cells' density in the synovial stroma on a scale of $0-3$. Synovitis scores obtained for both of these parameters were averaged separately, and the sum of averages from both parameters used for analysis on a scale of $0-6$.

\section{Immunostaining for Postn and MMP-13}

Histological sections were deparaffinized using xylene and then rehydrated in a graded series of ethyl alcohol. Endogenous peroxidase activity quenched by incubating slides with $3 \%(\mathrm{v} / \mathrm{v})$ hydrogen peroxide in phosphate-buffered saline (PBS). After 15 min of incubation, proteinase $\mathrm{K}(10 \mu \mathrm{g} /$ $\mathrm{mL}$, Abcam, Cambridge, MA) was added to the sections for $20 \mathrm{~min}$ at $37^{\circ} \mathrm{C}$ to retrieve the antigen. Following washing with PBS and blocking with $10 \%$ normal goat serum (NGS), slides were allowed to react overnight at $4{ }^{\circ} \mathrm{C}$ with the following primary antibodies diluted in $2 \%$ NGS: antiperiostin (1:100, Sigma-Aldrich, St. Louis, MO), MMP-13 (1:200, Abcam), and in-house collagen type II (Col 2, 1: 200). The next day, following the washing step, slides were incubated with the corresponding HRP- (for Postn), Alexa 488-(MMP-13), or Alexa 594-(for Col 2) conjugated secondary antibody in 2\% NGS for one-hour room temperature. Then, slides (MMP-13 and Col 2) underwent counterstaining with Fluoro-Gel II with 4',6-diamidino-2phenylindole (DAPI, Electron Microscopy Sciences, Hatfield, PA) for MMP-13 and Col 2. For immunohistochemical staining of Postn, HRP stained slides were developed with 3,3'-Diaminobenzidine (DAB Chromogen Kit; Vector Laboratories Inc., Burlingame, CA) for $10 \mathrm{~min}$ at room temperature. All images were visualized using a NanoZoomer (Hamamatsu Corp., Bridgewater, NJ) or Confocal Laser Scanning Microscope (Leica, Biosystems, Buffalo Grove, IL). MMP-13 expression levels were quantified by measuring the staining intensity of $20-40$ cells in each stained section using LAS X software (Leica Biosystems).

\section{$\mu \mathrm{CT}$ analysis of the trabecular bone}

After fixation but before decalcification, the knees undergoing DMM were scanned using a vivaCT 40 in vivo $\mu \mathrm{CT}$ scanner (Scanco Medical Inc., Southeastern, PA) with the following setting: voxel size $=21 \mu \mathrm{m}$, energy $=45 \mathrm{kV}$, intensity $=177 \mu \mathrm{A}$, and integration time $=300 \mathrm{~ms}$ [34]. To analyze bone changes, the femoral epiphysis was chosen as the region of interest. The region of interest was identified between the cartilage and the growth plate. The outline of the epiphysis was carefully selected without the inclusion of outgrowing osteophyte(s). Knees from 24-month-old mice were scanned using a $10 \mathrm{MP}$ digital detector using the following parameters: $10 \mathrm{~W}$ of energy $(50 \mathrm{kV}$ and $200 \mathrm{~mA})$, pixel size $=9.7 \mu \mathrm{m}$, exposure $=1025 \mathrm{~ms} /$ frame, rotation step 0.3 degrees with $\times 10$ frames averaging, $0.5 \mathrm{~mm}$ Aluminum filter, and scan rotation $=180^{\circ}$. After scanning, the radiographs were reconstructed using NRecon software ver. 1.7.3.0 (Bruker $\mu \mathrm{CT}$, Kontich, Belgium). Reconstruction was done with NRecon using GPU acceleration. Gaussian smoothing was applied with a 2-voxel radius, ring artifact, and beam hardening corrections were applied in reconstruction. Ring artifact reduction set to 7 pixels. Beam hardening correction was set to $40 \%$. Following trabecular bone morphometric parameters defined by the American Society for Bone and Mineral Research were analyzed [35]: bone volume fraction (BV/TV), volumetric bone mineral density (vBMD), trabecular thickness (Tb.Th), trabecular number (Tb.N), and trabecular spacing (Tb.Sp).

\section{RNA-Seq analysis, gene ontology annotation, and transcript expression validation}

We performed bulk RNA-seq on articular chondrocytes isolated from Postn $^{-/-}$and $w t$ mice to determine the baseline transcript-level differences between the two genotypes.

\section{Chondrocyte isolation and culture}

Primary chondrocytes were isolated from femoral head cartilage of 21-day-old Postn ${ }^{-1-}(n=3)$ and $w t(n=3)$ mice as described previously [36]. The cells were seeded in 24-well plates, supplied with $10 \%$ fetal bovine serum (FBS; Thermo Fisher Scientific, Waltham, MA) in high glucose Dulbecco's modified Eagle's medium (DMEM; Thermo Fisher Scientific) supplemented with $1 \%$ penicillin and streptomycin $(10,000 \mathrm{U} / \mathrm{mL}$ and $10,000 \mathrm{ug} / \mathrm{mL}$ respectively;, Thermo Fisher Scientific) and incubated at $37^{\circ} \mathrm{C}$ in a humidified incubator with $5 \% \mathrm{CO}_{2}$. After 2 days of culture, cells were washed $3 \times$ with PBS before RNA extraction.

\section{RNA extraction}

Total RNA was extracted from $1.0 \times 10^{5}$ cells using a column-based RNeasy Mini kit (Qiagen, Valencia, CA). Total RNA quality and concentrations were measured using Agilent Bioanalyzer (Agilent Technologies Inc., Santa Clara, CA). RNA samples with a RIN (RNA integrity number) score $>9.0$ were used for RNA-seq analysis and real-time PCR.

\section{Library preparation, sequencing, and gene ontology analysis}

Library preparation was performed with $10 \mathrm{ng}$ of total RNA. Double-stranded cDNA was prepared using Clontech SMARTer Ultra Low RNA kit (Takara Bio Inc., Mountain View, CA). cDNA was fragmented with an E220 sonicator (Covaris Inc., Woburn, MA) using these settings: peak incident power $=18$, duty factor $=20 \%$, and cycles per burst $=50$ for $120 \mathrm{~s}$. cDNA was bluntended, had an A base added to the 3' ends, and had Illumina sequencing adapters ligated to the ends. Ligated fragments were amplified for $12-15$ cycles using primers incorporating unique dual index tags. Fragments were sequenced on an Illumina HiSeq 3000 (Illumina, San 
Diego, CA) using single-end reads extending 50 bases. Base calls and demultiplexing performed with Illumina's bcl2fastq software, and a custom python demultiplexing program with a maximum of one mismatch in the indexing read. RNA-seq reads were aligned to the Ensembl release 76 top-level assemblies with STAR version 2.0.4b [37]. Gene counts were derived from the number of uniquely aligned unambiguous reads by Subread:featureCount version 1.4.5 [38]. Sequencing performance was assessed for the total number of aligned reads, the total number of uniquely aligned reads, and features detected. The ribosomal fraction, known junction saturation, and read distribution over known gene models were quantified with RSeQC version 2.3 [39].

All gene counts imported into the R/Bioconductor package EdgeR [40], and TMM normalization size factors were calculated to adjust for samples for differences in library size. Ribosomal genes and genes not expressed in the smallest group size minus one sample greater than one count-per-million excluded from further analysis. The TMM size factors and the matrix of counts were then imported into the R/Bioconductor package Limma [41]. Weighted likelihoods based on the observed meanvariance relationship of every gene and sample were then calculated for all samples with the voomWithQualityWeights [42] function with additional unknown latent effects as determined by surrogate variable analysis [43]. All genes performance assessed with plots of the residual standard deviation of every gene to their average logcount with a robustly fitted trend line of the residuals. Differential expression analysis was performed to analyze for differences between conditions, and the results were filtered for only those genes with Benjamini-Hochberg false-discovery rate (FDR) adjusted $P \leq 0.05$.

For each contrast extracted with Limma, global perturbations in known Gene Ontology (GO) terms detected using the R/Bioconductor package "Generally Applicable Gene set Enrichment" [44] to test for changes in expression of the reported $\log _{2}$-fold changes reported by Limma in each term versus the background $\log _{2}$-fold of all genes found outside the respective term. The R/Bioconductor package heatmap3 [45] used to display heatmaps across groups of samples for each GO term with a Benjamini-Hochberg FDR-adjusted $P \leq 0.05$.

\section{Validation of RNA-seq data by quantitative real-time $P C R$}

We validated RNA-seq data by quantitative real-time PCR. We selected representative genes for each pattern of expression. Expression of Dscaml1 and Tm4sf1 was higher in Postn ${ }^{-/-}$and $w t$ mice respectively, expression of Ndufs5 and Srsf10 was similar in both groups. Total RNA was prepared from chondrocytes isolated from Post $^{-1-}$ mice $(n=6)$ and $w t$ mice $(n=6)$ mice. A total of 250 ng of total RNA was subjected to Amplification Grade
DNase I treatment (1 U/ $\mu \mathrm{L}$, Thermo Fisher Scientific), to eliminate traces of genomic DNA and then reverse transcribed to synthesize the first strand of cDNA (High-Capacity Reverse Transcription Kit, Thermo Fisher Scientific). Briefly, $2 \mu \mathrm{L}$ cDNA was added to the reaction mixture comprising of $2 \times$ SYBR Green Master Mix (Thermo Fisher Scientific), gene-specific forward and reverse primers (primer sequences are depicted in Table 2), and RNase-free water to reach a total volume of $20 \mu \mathrm{L}$. Subsequently, real-time PCR was performed under the following settings: $94^{\circ} \mathrm{C}$ for $3 \mathrm{~min}$, followed by 40 cycles at $94{ }^{\circ} \mathrm{C}$ for $30 \mathrm{~s}, 60^{\circ} \mathrm{C}$ for $30 \mathrm{~s}$, and $72{ }^{\circ} \mathrm{C}$ for $30 \mathrm{~s}$. The target gene expression was normalized to the housekeeping gene, Gapdh. Each analysis was performed in triplicate. The relative expression values were computed using $2^{-\Delta \Delta} \mathrm{Ct}$ method.

\section{Statistical analysis}

The non-parametric Mann-Whitney test used to compare the data from two genotypes ( $w t$ and Postn $^{-1-}$ ) unless indicated otherwise. Results were considered statistically significant at $P<0.05$. Data are presented as mean \pm standard deviation with $95 \%$ confidence interval (CI) where indicated. All statistical analyses were performed using GraphPad PRISM version 7.03 (GraphPad Software Inc., San Diego, CA).

\section{Results \\ Postn $^{-/-}$mice exhibit no Postn in the joint and in the serum}

The genotype of each mouse was confirmed by PCR (Fig. 1a-c). We demonstrated a complete loss of Postn protein in Postn $^{-/-}$mice by immunostaining of the joint section (Fig. 1d) and ELISA in serum. ELISA results revealed significantly low levels of Postn protein in the serum of Postn $^{-1-}$ mice compared with the wt mice $(28.33 \pm 21.65 \quad[95 \% \quad \mathrm{CI}=-4.88-61.55] \quad$ vs. $3827.00 \pm$ 2504.00 [95\% CI = 2144.00-5509.00], $P=0.0002$ ) (Fig. 1e).

\section{Postn $^{-1-}$ mice develop less severe OA after DMM Cartilage degeneration}

The analysis of histological sections of DMM-operated or non-operated knees from Postn ${ }^{-/-}$and $w t$ mice at 8-weeks after DMM surgery (Fig. 2a) showed that non-operated control mice retained relatively normal cartilage with maximum OARSI score $\leq 1.00$. Conversely, many histological features representative of OA were apparent 8 weeks after surgery in $w t$ mice: reduced Safranin $\mathrm{O}$ staining depicting proteoglycan loss in the ECM, fibrillation, and delamination of superficial zone cartilage, and in severe cases, an extension of the cleft lesions into the middle zone. These features illustrate that DMM surgery-induced degeneration of the cartilage resembles human OA pathology. The mean maximum OARSI score for $w t$ mice in DMM-operated knees 
Table 2 Sequence and characteristics of primers used for real-time PCR

\begin{tabular}{lllllll}
\hline Gene symbol & Forward primer $\left(\mathbf{5}^{\prime} \rightarrow \mathbf{3}^{\prime}\right)$ & Location & Reverse primer $\left(\mathbf{5}^{\prime} \boldsymbol{\rightarrow} \mathbf{3}^{\prime}\right)$ & Location & Amplicon size & Accession no. \\
\hline Dscam/1 & aggctgaagaggctacgaga & $4972-4991$ & gaggtcctttcacaggggtg & $5062-5043$ & $91 \mathrm{bp}$ & NM_001081270.2 \\
Tm4sf1 & actgggtttggcagaaggac & $1006-1025$ & tgggctcatagcacttggac & $1127-1108$ & $122 \mathrm{bp}$ & NM_008536.4 \\
Ndufs5 & acagccctataagaacgccg & $148-167$ & tgtaccgaagcaagcactct & $287-268$ & $140 \mathrm{bp}$ & NM_001030274.1 \\
Srsf10 & acgtcgggaatttggtcgtt & $234-253$ & agcgtcttcagcatcacgaa & $357-338$ & $124 \mathrm{bp}$ & NM_010178.3 \\
Gapdh & aggtcggtgtgaacggatttg & $100-120$ & tgtagaccatgtagttgaggtca & $222-200$ & $123 \mathrm{bp}$ & NM_001289726.1 \\
\hline
\end{tabular}

$b p=$ base pair

$(4.00 \pm 1.20 ; 95 \% \mathrm{CI}=3.00-5.00)$ was significantly $(P<$ 0.001 ) higher than that of non-operated control knees $(0.75 \pm 0.46 ; 95 \% \mathrm{CI}=0.36-1.14)$. Postn $^{-/-}$mice that underwent DMM showed significantly less cartilage damage with the mean maximum OARSI score of $2.37 \pm 0.74$ (95\% CI $=1.75-3.00)$, significantly $(P=0.011)$ lower than for their littermate $w t$ mice $(4.00 \pm 1.20$; $95 \% \mathrm{CI}=3.00-$ 5.00) (Fig. 2b). Likewise, DMM-operated Postn ${ }^{-/-}$mice $(9.31 \pm 2.52,95 \% \mathrm{CI}=7.21-11.42)$ had significantly $(P=$ $0.0002)$ lower mean summed OARSI score than $w t$ mice (21.44 $\pm 6.01,95 \% \mathrm{CI}=16.41-26.46)$ (Fig. 2c).

\section{Synovitis}

We noted a thinner synovial lining cell layer and a low density of cells in the synovial stroma in Postn ${ }^{-/-}$mice than $w t$ mice (Fig. 2d). Quantification of synovitis score was significantly $(P=0.039)$ lower in $P_{0 s t n^{-1-}}$ mice
$(1.88 \pm 1.01 ; 95 \% \mathrm{CI}=0.82-2.93)$ than $w t$ mice $(3.17 \pm$ 0.63; 95\% CI = 2.51-3.82) (Fig. 2e).

\section{Trabecular bone changes}

Interestingly, there were no differences in the bone parameters measured in the control/contralateral limbs between the genotypes (Table 3). The differences in the various parameters of trabecular bone between $w t$ and Postn $^{-1-}$ are shown in Fig. 2f. We noted that the following bone parameters were significantly lower in Postn ${ }^{-/-}$ mice compared with $w t$ mice: trabecular BV/TV $(9.8 \%$, $P=0.009)$, vBMD (11.3\%, $P=0.029)$, Tb.Th $(25.6 \%, P=$ $0.043)$, and Tb.N (14.6\%, $P=0.012)$. In contrast, Tb. Sp was significantly higher in $P_{0 s t n}^{-/-}$mice than wt mice (17.2\%, $P=0.023)$.

\begin{tabular}{ccccc}
\cline { 2 - 4 } & Primer name & Primer type & Sequence $\mathbf{5}^{\prime} \rightarrow \mathbf{3}^{\prime}$ & Amplicon size \\
\cline { 2 - 4 } & Common & ccttgccagtctcaatgaagg & - \\
8440 & Wild-type reverse & tgacagagtgaacacatgcc & $691 \mathrm{bp}$ \\
olMR1030 & Mutant reverse & ggaagacaatagcaggcatgctg & $500 \mathrm{bp}$ \\
\hline
\end{tabular}

B

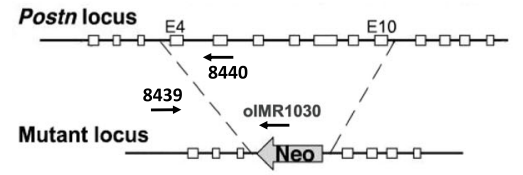

C

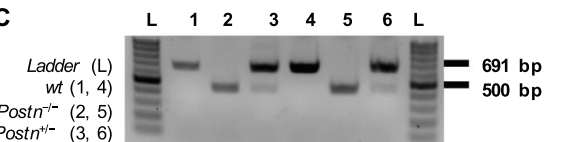

E

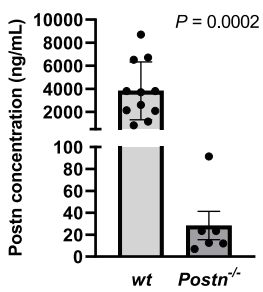

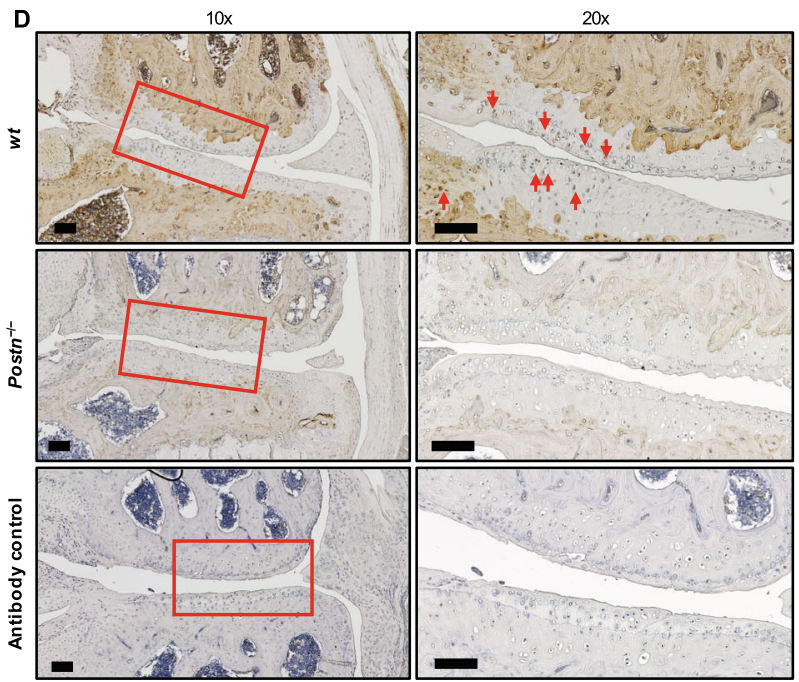

Fig. 1 Postn $^{-/}$mice lack Postn protein. a Primers used for mouse genotyping. b Diagram of targetting vector for genertaion of Postn ${ }^{-/-}$mice. $\mathbf{c}$ Genotyping analysis of $w t$, Postn ${ }^{-/-}$and Postn ${ }^{+/-}$mice. $\mathbf{d}$ Immunostaining of Postn in the knee joint revealed that wt $(n=3)$ mice expressed periostin (red arrows) whereas Postn ${ }^{-1-}(n=3)$ mice showed no staining for Postn (left panel: 10x, right panel 20x). Scale bar $=100 \mu \mathrm{m}$. e Serum Postn levels were negligible and significantly low in Postn ${ }^{-1-}(n=6)$ than wt mice $(n=11)$ (Mann-Whitney test) 

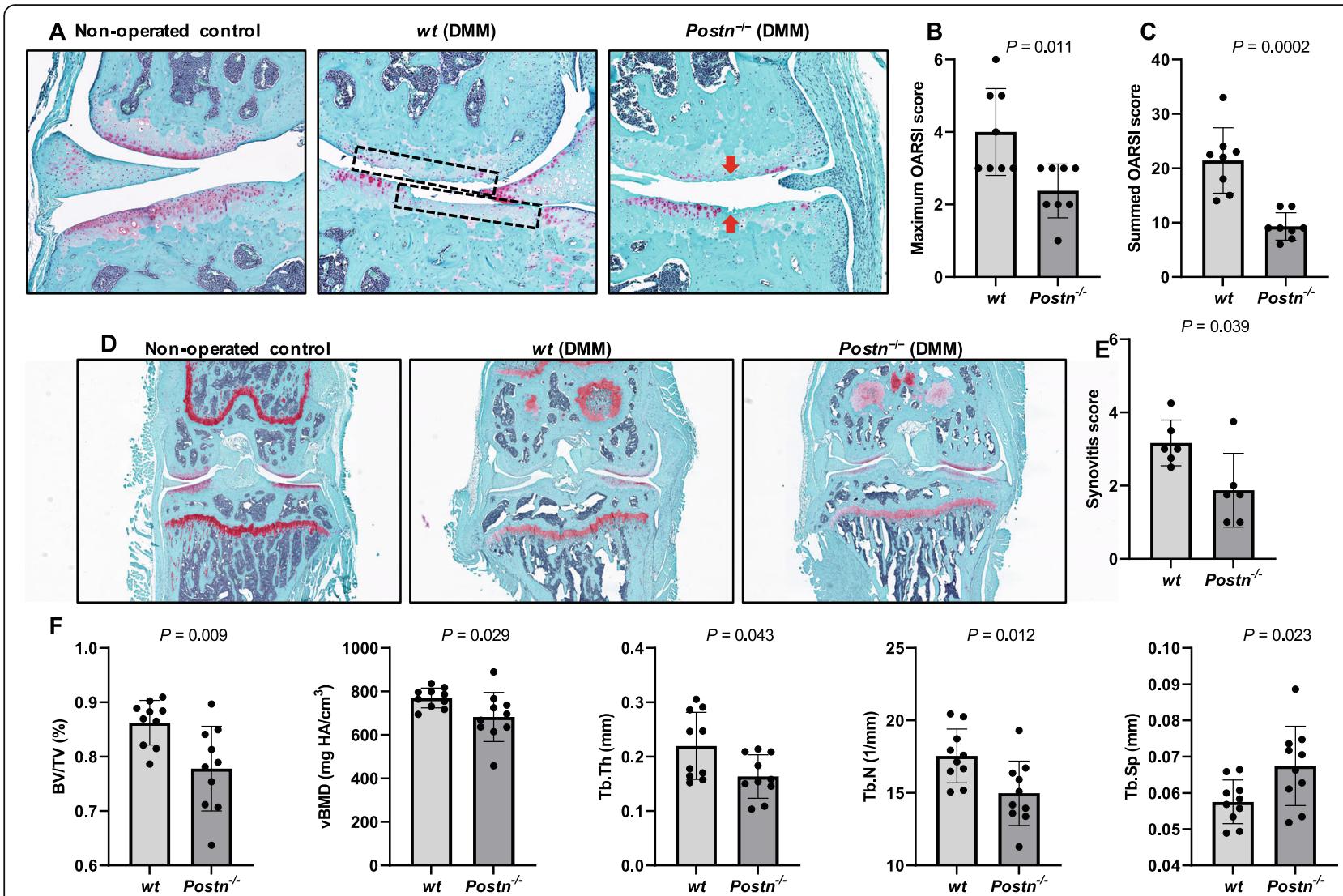

Fig. 2 Postn $^{-1-}$ mice are protected from post-traumatic OA. a Histological analysis of the cartilage showed that DMM-operated limbs exhibited increased cartilage degeneration than non-operated control limbs. Cartilage degeneration in wt mice was markedly higher (dotted boxes) than Post $n^{-1-}$ mice (arrows). b Semi-quantitative analysis of cartilage degeneration by maximum OARSI score showed that Postn ${ }^{-1-}$ mice $(n=8)$ had significantly less maximum OARSI score than wt mice $(n=8)$. (Mann-Whitney test). c Semi-quantitative analysis of cartilage degeneration by summed OARSI score showed that Postn ${ }^{-1}$ mice $(n=8)$ had significantly less summed OARSI score than wt mice $(n=8)$. (Mann-Whitney test). d Synovitis was evaluated by measuring synovial lining cell layer and density of cells in the synovial stroma. e Semi-quantification of synovitis score was significantly lower in Postn ${ }^{-1-}$ mice $(n=6)$ than wt mice $(n=6)$. (Mann-Whitney test). $\mathbf{f} \mu \mathrm{CT}$ analysis showed that Postn ${ }^{-1-}$ mice $(n=10)$ had significantly lower BV/ TV. vBMD, Tb.Th and Tb.N and significantly higher Tb. Sp than wt mice $(n=10)$ in the DMM-operated limb (Mann-Whitney test)

\section{4-month-old Postn ${ }^{-/-}$mice demonstrated protection from spontaneous $\mathrm{OA}$ \\ Cartilage degeneration}

Representative histological sections from 24-month-old Postn $^{-1-}$ and $w t$ mice are shown in Fig. 3a. Histological analysis of the knee joints of 24-month-old Postn $^{-1-}$ and $w t$ mice showed that Postn ${ }^{-1-}$ mice had less cartilage degeneration (only focal loss of proteoglycans without cartilage loss) than wt mice, which exhibited increased loss of cartilage proteoglycan and delamination of both superficial and middle zones. These observations confirmed that in mice, aging induces spontaneous cartilage degeneration that resembles OA pathology in humans. The mean maximum OARSI score in Postn ${ }^{-1-}$ mice was significantly lower than in $w t$ mice $(1.93 \pm 0.45[95 \% \mathrm{CI}=$ $1.51-2.35]$ vs. $3.58 \pm 1.16,[95 \% \mathrm{CI}=2.37-4.80], P=$

Table 3 Bone epiphysial parameters in control limbs of wt and Postn ${ }^{-1}$ mice

\begin{tabular}{|c|c|c|c|c|c|}
\hline \multirow[t]{2}{*}{ Parameter } & \multicolumn{2}{|l|}{$w t$} & \multicolumn{2}{|l|}{ Postn ${ }^{-1-}$} & \multirow{2}{*}{$\begin{array}{l}P \\
\text { value }\end{array}$} \\
\hline & Mean \pm SD & $95 \% \mathrm{Cl}$ & Mean \pm SD & $95 \% \mathrm{Cl}$ & \\
\hline $\mathrm{BV} / \mathrm{TV}\left(\mathrm{mm}^{3} / \mathrm{mm}^{3}\right)$ & $0.79 \pm 0.04$ & $0.76-0.82$ & $0.73 \pm 0.09$ & $0.66-0.79$ & 0.143 \\
\hline $\mathrm{VBMD}\left(\mathrm{mg} \mathrm{HA} / \mathrm{cm}^{3}\right)$ & $650.70 \pm 57.35$ & $609.70-691.70$ & $608.90 \pm 103.60$ & $534.70-682.90$ & 0.436 \\
\hline Tb.Th (mm) & $0.20 \pm 0.11$ & $0.13-0.28$ & $0.15 \pm 0.03$ & $0.13-0.17$ & 0.248 \\
\hline Tb.N (1/mm) & $14.46 \pm 2.54$ & $12.64-16.28$ & $15.33 \pm 2.87$ & $13.28-17.39$ & 0.631 \\
\hline Tb.Sp (mm) & $0.07 \pm 0.02$ & $0.06-0.08$ & $0.06 \pm 0.01$ & $0.05-0.07$ & 0.353 \\
\hline
\end{tabular}

SD standard deviation, $\mathrm{Cl}$ confidence interval 


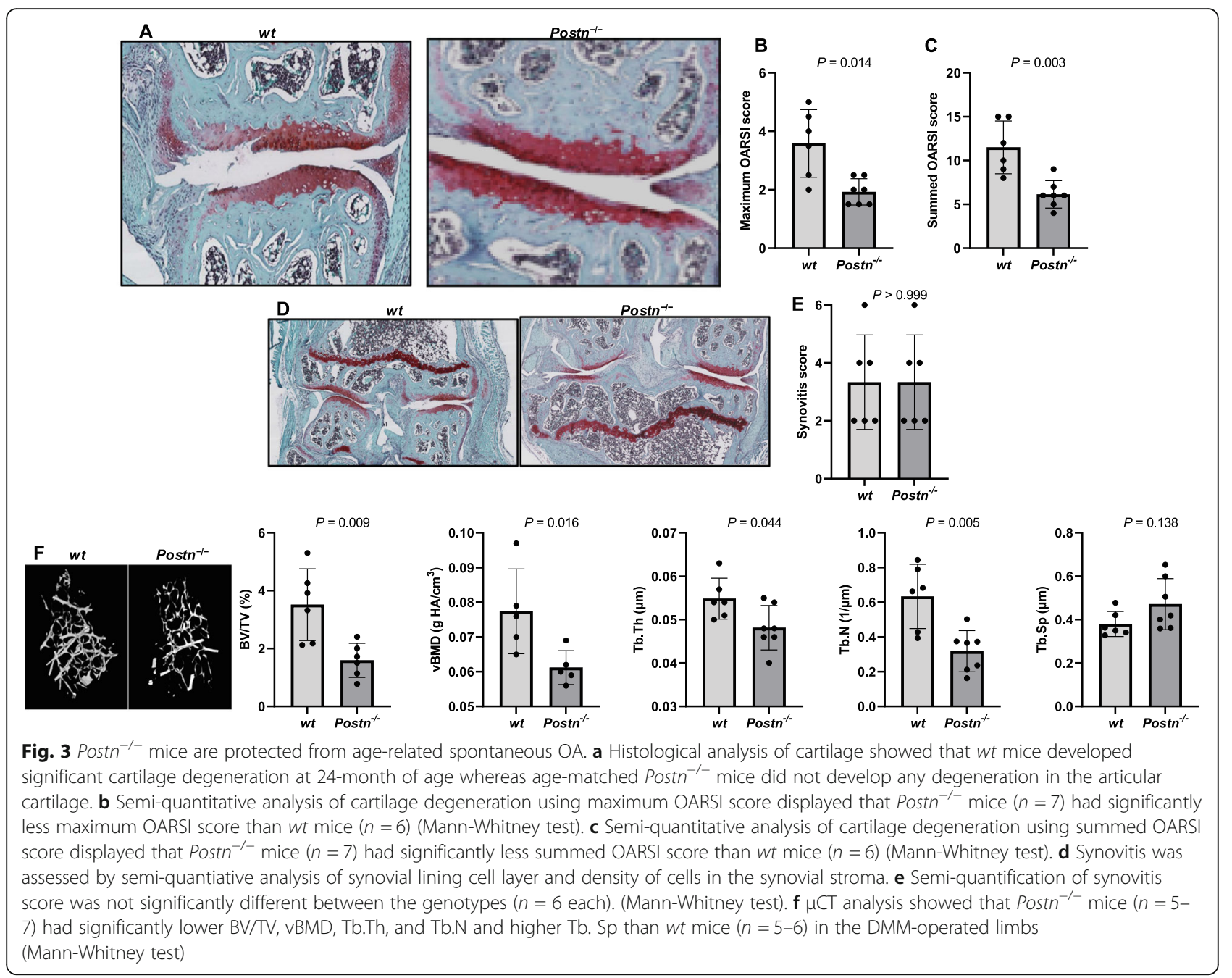

0.014) (Fig. 3b). Similarly, the mean summed OARSI score was significant $(P=0.003)$ lower in Postn ${ }^{-/-}$mice $(6.14 \pm 1.57,95 \% \mathrm{CI}=4.69-7.60)$ than $w t$ mice $(11.50 \pm$ 3.02, 95\% CI = 8.33-14.67) (Fig. 3c).

\section{Synovitis}

The synovial lining cell layer and cell density in the synovial stroma appeared similar in both genotypes (Fig. $3 \mathrm{~d})$. We did not find any significant $(P>0.999)$ difference in synovitis score between Postn $^{-/-}$mice (3.33 \pm 1.63; $95 \% \mathrm{CI}=1.62-5.05)$ and $w t$ mice $(3.33 \pm 1.63$; $95 \%$ $\mathrm{CI}=1.62-5.05)$ (Fig. 3e).

\section{Trabecular bone changes}

The changes in different trabecular bone parameters are depicted in Fig. 3f. We observed that Postn ${ }^{-/-}$mice exhibited significantly lower trabecular BV/TV $(54.7 \%, P=$ 0.009), vBMD (20.9\%, $P=0.016)$, Tb.Th $(12.2 \%, P=$ $0.044)$ and Tb.N $(49.7 \%, P=0.005)$ in contrast to $w t$ mice. Also, Tb. Sp was $24.0 \%$ higher in Postn ${ }^{-1-}$ than $w t$ mice but did not reach significance $(P=0.138)$.

\section{MMP-13 expression decreased in Postn ${ }^{-/-}$mice}

Immuno-fluorescence analysis of MMP-13 revealed that its expression was increased in $w t$ mice following DMM compared with the control knees. In contrast, no MMP13 was detected in DMM-operated knees of Postn ${ }^{-/}$ mice (Fig. 4a). Semi-quantitative assessment of immunofluorescence imaging further showed that intensity of MMP-13 staining was significantly $(P=0.029)$ lower in Postn $^{-1-}(6.73 \pm 5.23,95 \% \mathrm{CI}=-1.60-15.06)$ than $w t$ mice $(28.18 \pm 14.94,95 \% \mathrm{CI}=4.42-51.95)$ (Fig. $4 \mathrm{~b})$.

\section{RNA-seq and gene ontology analyses}

Qualitative gene expression analysis revealed that samples were clustered into two distinct clusters of Postn ${ }^{-/}$ and $w t$ chondrocytes based on principal component analysis indicating a specific expression profile (Fig. 5a) though there was higher variation among samples from 

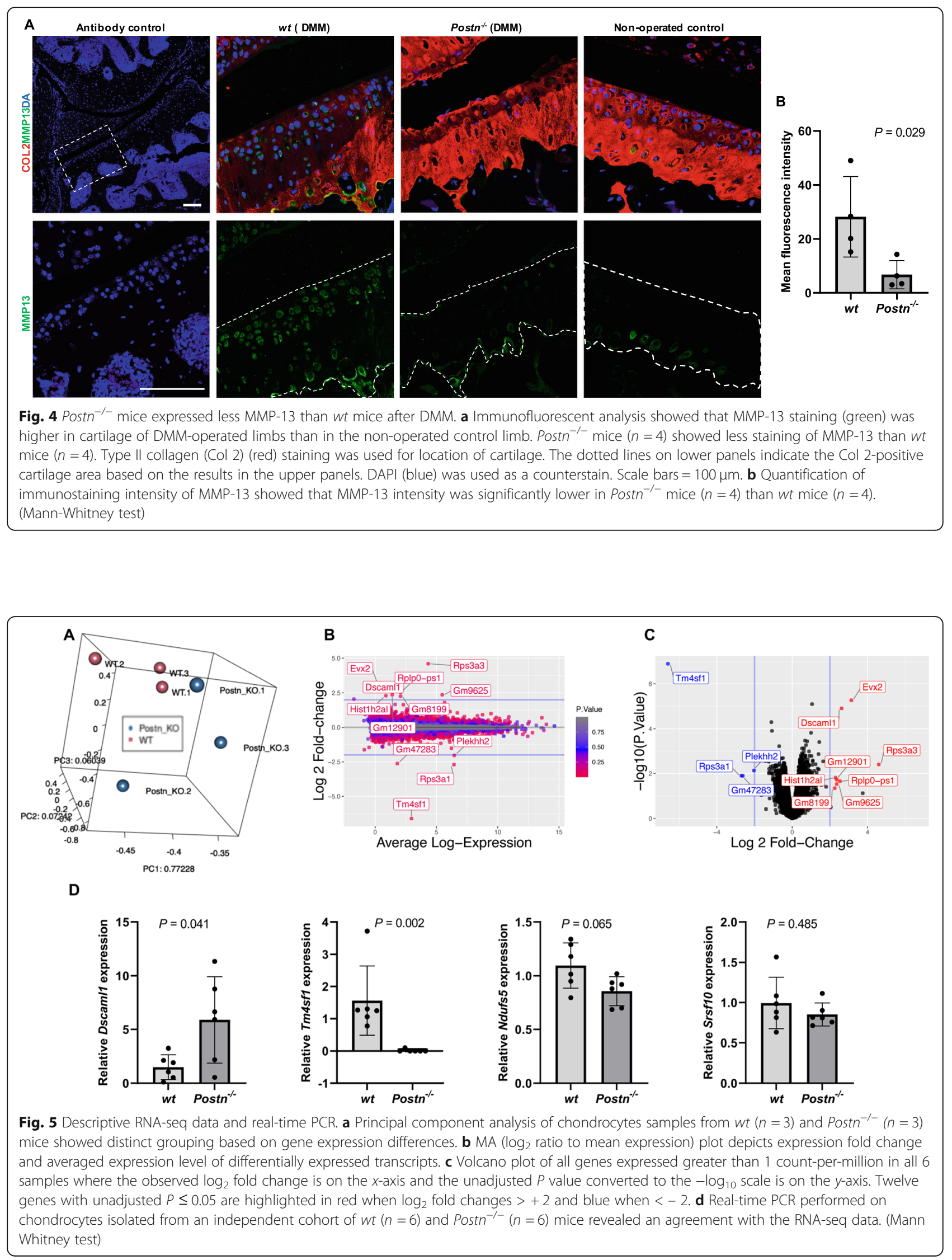
$w t$ mice than Postn ${ }^{-/-}$mice. Moreover, we show that expression fold change and average expression levels vary subtly in a mean average $\left(\log _{2}\right.$ ratio to mean expression plot) (Fig. 5b).

\section{Detection of differentially expressed gene transcripts}

Gene transcripts (Supplemental Table 1) were significantly differentially expressed $(n=1247)$ between Post $^{-/-}$and $w t$ chondrocytes at an unadjusted $P \leq 0.05$ with 727 being upregulated in Postn ${ }^{-/}$while 520 were upregulated in $w t$ chondrocytes. Out of 1247 , only 48 transcripts had $\log _{2}$ fold-change $\geq 2$. After, FDR $\leq 0.05$ correction, only four transcripts (Table 4) were found to be differentially expressed ( 3 upregulated and 1 downregulated) between Postn ${ }^{-/-}$compared with $w t$. Volcano plot of genes expressed greater than 1 count-per-million in all six samples is shown (Fig. 5c).

\section{Gene ontology annotation}

Gene ontology analysis revealed that a number of distinct biological processes were significantly enriched for each genotype (Table 5). While the biological processes related to cell-cell adhesion, cell signaling, cell differentiation, focal adhesion, and angiogenesis were elevated in Postn $^{-1-}$ mice, biological processes such as cell cycle, cell division, and DNA repair repressed in Postn ${ }^{-/}$mice.

\section{Validation by real-time $P C R$}

We further confirmed the differentially expressed genes by quantitative real-time PCR in agreement with the RNA-seq data (Fig. 5d).

\section{Discussion}

Our study illustrates that Postn deficiency exerts a protective effect against OA in mice. Specifically, mice lacking the Postn gene displayed significantly less cartilage degeneration than $w t$ control mice in post-traumatic OA as well as age-related primary OA. Postn deficiency also appears to wield protective effects by modulating changes in the synovium and bone. Thus, our findings highlight that Postn loss-of-function protects against incidence and progression of $\mathrm{OA}$ independent of the cause, i.e., primary age-related spontaneous $\mathrm{OA}$ as well as injury-induced post-traumatic OA.

In both mouse models of OA, Postn ${ }^{-/-}$mice retained superior cartilage and exhibited less degenerative changes as measured by OARSI scores. These findings are consistent with the notion that protection from cartilage degeneration parallels protection from $\mathrm{OA}$ since cartilage degeneration is considered OA's hallmark [4]. Besides, we also showed that Postn ${ }^{-/-}$mice developed significantly less synovitis than wt mice after DMM. Tajia et al. have also shown increased expression of Postn in human OA synovium [46]. These protective effects of Postn loss-of-function on the cartilage and synovium indicate decreased catabolic activity in the joint. Our observation aligns with our previous in vitro work showing that siRNA-mediated knockdown of Postn in chondrocytes results in reduced expression of inflammatory and catabolic markers such as IL-1 $\beta$, ADAMTS-4/5, and MMP-13 [12, 22].

We also found differences in trabecular bone parameters between the genotypes (Postn ${ }^{-1-}$ and $\left.w t\right)$ for both OA models. BV/TV, vBMD, Tb.Th, and Tb.N was low and Tb. Sp was high in Postn ${ }^{-1-}$ mice. These parameters are not only standard osteoporosis measurements but have also been used as markers for OA [47-49]. The pattern of these bony changes in Postn ${ }^{-/-}$mice mirrors OA protection as has been noted in rodent and human studies of OA [31, 47-52]. These findings suggest that Postn plays a role in modulating changes in cartilage as well as in the bone. However, it is not possible to conclude that the bone is driving the cartilage phenotype from this investigation.

In the present study, we did not examine how the genetic deficiency of Postn protects mice from developing OA. However, several studies suggest a possible link connecting the mechanisms of Postn-mediated cartilage degeneration with NF-kB and Wnt signaling [7, 12, 22, 53]. We have previously shown that Postn expression is increased following injury [12]. Postn is upregulated in human OA cartilage and cartilage from mice undergoing DMM and is correlated with increased MMP-13 expression in OA cartilage [12, 22]. Increased expression of Postn leads to overexpression of cartilage ECM degrading enzymes such as MMP-13 and ADAMTS-5. Postn also promotes condylar resorption via the NF- $\mathrm{kB}$ ADAMTS-5 axis in temporomandibular joint OA [54]. Overexpression of Postn by the administration of recombinant proteins or through lentivirus transduction leads to increased expression of MMP-13 in human and murine chondrocytes. Likewise, Postn inhibition or

Table 4 Gene transcripts differentially expressed in chondrocytes between Postn ${ }^{-1-}$ and wt mice

\begin{tabular}{lllll}
\hline Gene symbol & Gene name & Log $_{\mathbf{2}}$ fold change & $\boldsymbol{P}$ & Description \\
\hline Evx2 & Even skipped homeobox 2 & 3.14 & $5.30 \times 10^{-6}$ & Up-regulated in Postn ${ }^{-/-}$mice \\
Dscam/1 & DS cell adhesion molecule like 1 & 2.62 & $1.22 \times 10^{-5}$ & Up-regulated in Postn ${ }^{-/-}$mice \\
Gdf10 & Growth differentiation factor 10 & 1.05 & $7.85 \times 10^{-6}$ & Up-regulated in Postn ${ }^{-/-}$mice \\
Tm4sf1 & Transmembrane 4 superfamily member 1 & -6.59 & $1.27 \times 10^{-7}$ & Down-regulated in Postn ${ }^{-/-}$mice \\
\hline
\end{tabular}


Table 5 Biological processes (gene ontologies) altered in chondrocytes between Postn ${ }^{-/-}$and wt mice

\begin{tabular}{|c|c|c|c|c|c|}
\hline $\begin{array}{l}\text { Gene ontology term (elevated in Postn } \\
\text { mice) }\end{array}$ & $\begin{array}{l}\log _{2} \text { fold } \\
\text { change }\end{array}$ & FDR & $\begin{array}{l}\text { Gene ontology term } \\
\text { (repressed in Postn }{ }^{-/-} \text {mice) }\end{array}$ & $\begin{array}{l}\log _{2} \text { fold } \\
\text { change }\end{array}$ & FDR \\
\hline Cell-cell adhesion & 4.60 & $1.44 \times 10^{-3}$ & Mitotic cell cycle process & -7.75 & $2.99 \times 10^{-11}$ \\
\hline Regulation of developmental process & 4.70 & $1.09 \times 10^{-3}$ & Mitotic nuclear division & -6.77 & $1.64 \times 10^{-8}$ \\
\hline Regulation of response to stimulus & 5.06 & $3.01 \times 10^{-4}$ & Cell division & -7.39 & $3.16 \times 10^{-10}$ \\
\hline Blood vessel morphogenesis & 4.52 & $1.89 \times 10^{-3}$ & Chromosome organization & -7.06 & $1.30 \times 10^{-9}$ \\
\hline Cell differentiation & 4.62 & $1.34 \times 10^{-3}$ & Chromosome segregation & -8.17 & $1.25 \times 10^{-11}$ \\
\hline Regulation of signaling & 5.53 & $4.01 \times 10^{-5}$ & Cell cycle & -7.29 & $3.49 \times 10^{-10}$ \\
\hline Biological adhesion & 5.75 & $2.10 \times 10^{-5}$ & DNA repair & -7.79 & $2.99 \times 10^{-11}$ \\
\hline Regulation of cell communication & 5.53 & $4.01 \times 10^{-5}$ & DNA-dependent DNA replication & -6.61 & $8.23 \times 10^{-8}$ \\
\hline Regulation of signal transduction & 5.38 & $7.68 \times 10^{-5}$ & DNA replication & -6.36 & $1.51 \times 10^{-7}$ \\
\hline Angiogenesis & 4.47 & $2.03 \times 10^{-3}$ & Double-strand break repair & -5.85 & $4.04 \times 10^{-6}$ \\
\hline
\end{tabular}

deficiency results in decreased expression of catabolic enzymes. Therefore, we surmise that loss of Postn protects against cartilage degeneration by decreasing ECM degrading enzymes such as MMP-13 and ADAMTS-5. A recent study identified DDR-1 as a potential receptor for Postn-mediated signaling in chondrocytes. It showed that blocking DDR-1 with small chemical inhibitors reduced MMP-13 expression and cartilage degradation in vitro and in vivo [53].

Baseline transcriptomic differences between Postn $^{-/-}$ and $w t$ mice revealed interesting findings. The expression of Evx2, Dscaml1, and Gdf10 increased in Postn ${ }^{-1-}$ compared with $w t$ mice. Evx2 is predominantly expressed in the limbs and is involved in vertebrate limbs' morphogenesis, where it interacts with Hox genes [55]. Dscaml1 is a member of the immunoglobulin superfamily of cell adhesion molecules, which participates in neuronal differentiation [56]. Tuure et al. reported that the expression of Dscaml1 is low in human OA chondrocytes treated with IL-1 $\beta$ and is increased following treatment with a selective inhibitor of microsomal prostaglandin E synthase 1 [57]. Gdf10 gene encodes a secreted ligand of transforming growth factorbeta superfamily of proteins, which plays essential functions in chondrocyte differentiation and bone formation [58]. In particular, it was found that the expression of Gdf10 was increased in chondrocytes under hypoxia, where $G d f 10$ was regulated by Sox-9, suggesting its protective role in chondrocytes [59]. The expression of Tm4sf1 was decreased in Postn ${ }^{-/-}$mice. Tm4sf1 is a surface marker, known to inhibit apoptosis and promote cell proliferation and migration [60]. This transcriptomic profile paralleled with gene ontology annotations. For instance, the biological processes related to cell-cell adhesion, cell signaling, cell differentiation, and focal adhesion were elevated in Postn ${ }^{-/}$mice, while biological processes such as cell cycle, cell division, and proliferation were repressed in Postn ${ }^{-/-}$mice. Together, these findings provide novel insights into the role of Postn in chondrocytes, specifically highlighting that increased expression of Dscaml1 and Gdf10 (and related biological processes) offers protection from OA, while the expression of Tm4sf1 (and related biological processes) related to cellular phenotypes that are altered with Postn knockout. While the role of Postn in OA has been discussed in the previous paragraph, here, we highlight its role in cell functions. Chinzei et al. showed that exogenous overexpression of Postn increases chondrocyte migration which is impeded by its knockdown [22]. Likewise, Padial-Molina et al. reported an increase in proliferation and migration of periodontal ligament fibroblasts with Postn treatment [61]. Finally, Cai and colleagues showed that Postn knockdown decreases cell matrix [23]; however, no data are yet available for cell-cell-adhesion in the context of Postn knockdown or overexpression in chondrocytes.

Our finding that Postn deficiency reduces both agerelated spontaneous $\mathrm{OA}$ and post-traumatic $\mathrm{OA}$ is important. While aging and obesity are associated with primary idiopathic OA [62-65], joint injuries cause posttraumatic OA cases $[66,67]$ and constitute at least $12 \%$ of OA [68]. While both OA forms are qualitatively similar in that both share standard features such as cartilage degeneration and bone sclerosis [69], the underlying disease mechanisms are dissimilar in many ways [10]. However, their degree of overlap is unclear, particularly at the mechanistic level. Our finding that Postn deficiency protected the joint from cartilage degeneration and bone alterations in both types of OA suggests that Postn ablation may have widely applicable therapeutic efficacy. Specifically, anti-Postn therapy may have utility for primary idiopathic OA as well as for post-traumatic OA. 
In this study, we have shown that global deletion of Postn is protective against OA. Postn knockout is embryonically non-lethal, yet some Postn ${ }^{-/}$mice die shortly after birth. Surviving mice have $10-20 \%$ growth retardation and exhibit some skeletal abnormalities such as shorter subchondral bone, weaker ligaments, and moderate scoliosis (Cai et al. unpublished data), which complicate mechanistic exploration in a specific tissue, cartilage, for example. Thus, in future studies, we will disable Postn in a temporal (inducible) and cartilage-specific manner by genetic ablation in mature mice to study OA development.

This study has some limitations, we did not report data from heterozygotes $\left(\right.$ Postn $\left.^{+/-}\right)$since no protective effect was observed in those mice. Other limitations included the lack of measurement of functional outcomes such as behavior, pain, and gait as well as the lack of assessment of progressive changes as the only one-time point was studied in both models. Moreover, detailed analysis of osteophyte structure and histology is lacking. Another limiting factor was also difficulty to breed and raise Postn homozygous mice due to post-natal death of mice. Due to limiting number of mice available "sham" procedure could not be performed and could be a superior control for this model. Lastly, as we performed bulk RNA-seq only on primary chondrocytes, the findings should be interpreted within the context of cartilage. Since OA is considered a whole-joint disease and Postn plays a role in the bone and probably other parts of the joint, the lack of data from other tissue and cell types is a limitation.

\section{Conclusions}

In summary, Postn genetic loss-of-function protects against DMM-induced post-traumatic and age-related spontaneous OA. Our data identify Postn as a novel therapeutic target to delay or prevent $\mathrm{OA}$, independent of the cause despite aforementioned limitations. Further mechanistic studies are warranted to investigate the tissue-specific role(s) of Postn in OA and its impact on other knee tissues such as meniscus and ligaments. Postn modulating therapies will have to be identified and tested before these findings have translational value in the clinical setting.

\footnotetext{
Abbreviations

Postn: Periostin; OA: Osteoarthritis; wt: Wild type; DMM: Destabilization of the medial meniscus; MMP-13: Matrix metalloproteinase 13 (collagenase 3); PCR: Polymerase chain reaction; ELISA: Enzyme-linked immunosorbent assay; OARSI: Osteoarthritis Research Society International; $\mu \mathrm{CT}$ : Micro-computed tomography; PBS: Phosphate-buffered saline; NGS: Normal goat serum; COL2: Collagen type II; DAPI: 4', 6-Diamidino-2-phenylindole; BV/TV: Bone volume fraction; vBMD: Volumetric bone mineral density; Tb.Th: Trabecular thickness; Tb.N: Trabecular number; Tb.Sp: Trabecular spacing; FBS: Fetal bovine serum; DMEM: Dulbecco's modified Eagle's medium; RIN: RNA integrity number; FDR: False-discovery rate; GO: Gene ontology; Cl:: Confidence interval; ECM: Extracellular matrix; Evx2: Even skipped home box 2; Dscam/1: DS cell adhesion molecule like one; Gdf10: Growth differentiation factor 10; Tm4sf1: Transmembrane four superfamily member 1; Ndufs5: NADH:ubiquinone oxidoreductase core subunit S5; Srsf10: Serine/ arginine-rich splicing factor 10; Gapdh: Glyceraldehyde-3-phosphate
}

dehydrogenase; ADAMTS: A disintegrin and metalloproteinase with thrombospondin motif; NF-kB: Nuclear factor kappa-light-chain-enhancer of activated B cells; DDR-1: Discoidin domain receptor 1; IL-1ß: Interleukin 1 beta; Sox-9: SRY (sex-determining region Y) box transcription factor 9;

DAB: 3.3'-Diaminobenzidine

\section{Supplementary Information}

The online version contains supplementary material available at https://doi. org/10.1186/s13075-021-02477-z.

Additional file 1. Gene transcripts

\section{Acknowledgements}

The authors sincerely thank the critical technical assistance provided by Crystal Idleburg and Samantha Coleman from Histology \& Morphometry Core of the Musculoskeletal Research Center (NIAMS/NIH P30 AR074992, PI: Silva) at Washington University, St. Louis, MO. The authors much appreciate the support provided by the New York University $\mu \mathrm{CT}$ services (S10 OD010751). The authors also thank the Genome Technology Access Center at Washington University School of Medicine for RNA-seq analysis. The center is partially supported by NCI Cancer Center Support Grant P30 CA91842 to the Siteman Cancer Center and by ICTS/CTSA Grant UL1TR002345 from the NCRR, a component of the NIH and NIH Roadmap for Medical Research. This publication is solely the authors' responsibility and does not necessarily represent the official view of NIAMS, NCRR, or NIH.

\section{Authors' contributions}

All authors were involved in drafting the article or revising it critically for important intellectual content, and all authors approved the final version to be published. Drs. Attur and Rai had full access to all the data in the study and take responsibility for the integrity of the data and accuracy of the data analysis. Study conception and design. Mukundan Attur, Xin Duan, Lei Cai, Weili Zhang, Eric D. Tycksen, Robert H. Brophy, Steven Abramson and Muhammad Farooq Rai. Analysis and interpretation of data. Mukundan Attur, Xin Duan, Lei Cai, Tianzhen Han, Weili Zhang, Eric D. Tycksen, Robert H. Brophy, Steven Abramson, and Muhammad Farooq Rai.

\section{Author information}

Mukundan Attur and Xin Duan contributed equally to this work.

\section{Funding}

This study was supported by research funding by the Department of Orthopedic Surgery, Washington University School of Medicine, St. Louis, MO. Dr. Rai is also supported through the Pathway to Independence Award (R00 AR064837) from the National Institute of Arthritis and Musculoskeletal and Skin Diseases (NIAMS), National Institutes of Health (NIH). The study was also supported by the NIAMS (NIH) R01 AR052873 and R01 AR054817 to Dr. Abramson. The content of this publication is solely the responsibility of the authors and does not necessarily represent the official views of the $\mathrm{NIH}$ or NIAMS.

Availability of data and materials

RNA-seq data have been deposited to the GEO and are accessible through the accession number GSE164534 at https://www.ncbi.nlm.nih.gov/geo/. The other datasets generated and/or analyzed during the current study are not publicly available due to the limit of storage space but are available from the corresponding authors on a reasonable request.

\section{Declarations}

\section{Ethics approval and consent to participate}

All the animal studies were carried out in accordance with the recommendations in the Guide for the Care and Use of Laboratory Animals of the National Institutes of Health. All procedures were approved by the Institutional Animal Care and Use Committee (IACUC) of Washington University School of Medicine (Protocol No. 20190113) and New York University Grossman School of Medicine (Protocol No. s16-00601). 


\section{Consent for publication}

Not applicable

\section{Competing interests}

The authors declare that they have no competing interests.

\section{Author details}

'Division of Rheumatology, Department of Medicine, New York University Grossman School of Medicine, Langone Orthopedic Hospital, 550 1st Avenue, New York, NY 10016, USA. ²Department of Orthopaedic Surgery, Washington University School of Medicine at Barnes-Jewish Hospital MS 8233, 425 South Euclid Avenue, St. Louis, MO 63110, USA. ${ }^{3}$ Present address: Bluestone Center for Clinical Research, NYU College of Dentistry, New York, NY 10010, USA. ${ }^{4}$ Genome Technology Access Center, McDonell Genome Institute, Washington University School of Medicine, St. Louis 63110, MO, USA. ${ }^{5}$ Department of Cell Biology \& Physiology, Washington University School of Medicine, St. Louis 63110, MO, USA.

\section{Received: 26 January 2021 Accepted: 10 March 2021}

\section{Published online: 08 April 2021}

\section{References}

1. Kotlarz H, Gunnarsson CL, Fang H, Rizzo JA. Insurer and out-of-pocket costs of osteoarthritis in the US: evidence from national survey data. Arthritis Rheum. 2009;60(12):3546-53. https://doi.org/10.1002/art.24984.

2. Pereira D, Peleteiro B, Araujo J, Branco J, Santos RA, Ramos E. The effect of osteoarthritis definition on prevalence and incidence estimates: a systematic review. Osteoarthr Cartil. 2011;19(11):1270-85. https://doi.org/10.1016/j.joca.2 011.08.009.

3. Poole AR. Osteoarthritis as a whole joint disease. HSS J. 2012;8(1):4-6. https://doi.org/10.1007/s11420-011-9248-6.

4. Loeser RF, Goldring SR, Scanzello CR, Goldring MB. Osteoarthritis: a disease of the joint as an organ. Arthritis Rheum. 2012;64(6):1697-707. https://doi. org/10.1002/art.34453.

5. Poulet B. Models to define the stages of articular cartilage degradation in osteoarthritis development. Int J Exp Pathol. 2017;98(3):120-6. https://doi. org/10.1111/iep.12230

6. Lourido L, Calamia V, Mateos J, Fernandez-Puente P, Fernandez-Tajes J, Blanco FJ, Ruiz-Romero C. Quantitative proteomic profiling of human articular cartilage degradation in osteoarthritis. J Proteome Res. 2014;13(12): 6096-106. https://doi.org/10.1021/pr501024p.

7. Chijimatsu R, Kunugiza Y, Taniyama Y, Nakamura N, Tomita T, Yoshikawa H. Expression and pathological effects of periostin in human osteoarthritis cartilage. BMC Musculoskelet Disord. 2015;16(1):215. https://doi.org/10.1186/ s12891-015-0682-3.

8. Rousseau JC, Sornay-Rendu E, Bertholon C, Garnero P, Chapurlat R. Serum periostin is associated with prevalent knee osteoarthritis and disease incidence/progression in women: the OFELY study. Osteoarthr Cartil. 2015; 23(10):1736-42. https://doi.org/10.1016/j.joca.2015.05.015.

9. Honsawek S, Wilairatana V, Udomsinprasert W, Sinlapavilawan P, Jirathanathornnukul N. Association of plasma and synovial fluid periostin with radiographic knee osteoarthritis: cross-sectional study. Joint Bone Spine. 2015;82(5):352-5. https://doi.org/10.1016/j.jbspin.2015.01.023.

10. Loeser RF, Olex AL, McNulty MA, Carlson CS, Callahan MF, Ferguson CM, Chou J, Leng $X$, Fetrow JS. Microarray analysis reveals age-related differences in gene expression during the development of osteoarthritis in mice. Arthritis Rheum. 2012;64(3):705-17. https://doi.org/10.1002/art.33388.

11. Chou CH, Wu CC, Song IW, Chuang HP, Lu LS, Chang JH, Kuo SY, Lee CH, Wu JY, Chen YT, Kraus V, Lee MTM. Genome-wide expression profiles of subchondral bone in osteoarthritis. Arthritis Res Ther. 2013;15(6):R190. https://doi.org/10.1186/ar4380.

12. Attur $M$, Yang $Q$, Shimada $K$, Tachida $Y$, Nagase $H$, Mignatti $P$, Statman L, Palmer G, Kirsch T, Beier F, Abramson SB. Elevated expression of periostin in human osteoarthritic cartilage and its potential role in matrix degradation via matrix metalloproteinase-13. FASEB J. 2015;29(10):4107-21. https://doi. org/10.1096/fj.15-272427

13. Coutu DL, Wu JH, Monette A, Rivard GE, Blostein MD, Galipeau J. Periostin, a member of a novel family of vitamin K-dependent proteins, is expressed by mesenchymal stromal cells. J Biol Chem. 2008:283(26):17991-8001. https:// doi.org/10.1074/jbc.M708029200.
14. Takeshita S, Kikuno R, Tezuka K, Amann E. Osteoblast-specific factor 2: cloning of a putative bone adhesion protein with homology with the insect protein fasciclin I. Biochem J. 1993;294(Pt 1):271-8. https://doi.org/10.1042/ bj2940271.

15. Horiuchi K, Amizuka N, Takeshita S, Takamatsu H, Katsuura M, Ozawa H, Toyama Y, Bonewald LF, Kudo A. Identification and characterization of a novel protein, periostin, with restricted expression to periosteum and periodontal ligament and increased expression by transforming growth factor beta. J Bone Miner Res. 1999;14(7):1239-49. https://doi.org/10.1359/ jbmr.1999.14.7.1239.

16. Conway SJ, Izuhara K, Kudo Y, Litvin J, Markwald R, Ouyang G, Arron JR, Holweg $C T$, Kudo A. The role of periostin in tissue remodeling across health and disease. Cell Mol Life Sci. 2014:71(7):1279-88. https://doi.org/10.1007/ s00018-013-1494-y.

17. Litvin J, Selim AH, Montgomery MO, Lehmann K, Rico MC, Devlin H, Bednarik DP, Safadi FF. Expression and function of periostin-isoforms in bone. J Cell Biochem. 2004;92(5):1044-61. https://doi.org/10.1002/jcb.20115.

18. Zhu S, Barbe MF, Amin N, Rani S, Popoff SN, Safadi FF, Litvin J. Immunolocalization of Periostin-like factor and Periostin during embryogenesis. J Histochem Cytochem. 2008;56(4):329-45. https://doi.org/1 0.1369/jhc.7A7321.2007.

19. Ma D, Zhang R, Sun Y, Rios HF, Haruyama N, Han X, Kulkarni AB, Qin C, Feng JQ. A novel role of periostin in postnatal tooth formation and mineralization. J Biol Chem. 2011;286(6):4302-9. https://doi.org/10.1074/jbc. M110.140202.

20. Norris RA, Damon B, Mironov V, Kasyanov V, Ramamurthi A, MorenoRodriguez R, Trusk T, Potts JD, Goodwin RL, Davis J, Hoffman S, Wen X, Sugi Y, Kern CB, Mjaatvedt CH, Turner DK, Oka T, Conway SJ, Molkentin JD, Forgacs G, Markwald RR. Periostin regulates collagen fibrillogenesis and the biomechanical properties of connective tissues. J Cell Biochem. 2007:101(3): 695-711. https://doi.org/10.1002/jcb.21224.

21. Hamilton DW. Functional role of periostin in development and wound repair: implications for connective tissue disease. J Cell Commun Signal. 2008:2(1-2):9-17. https://doi.org/10.1007/s12079-008-0023-5.

22. Chinzei N, Brophy RH, Duan X, Cai L, Nunley RM, Sandell L, Rai MF. Molecular influence of anterior cruciate ligament tear remnants on chondrocytes: a biologic connection between injury and osteoarthritis. Osteoarthr Cartil. 2018; 26(4):588-99. https://doi.org/10.1016/j.joca.2018.01.017.

23. Cai L, Brophy RH, Tycksen ED, Duan X, Nunley RM, Rai MF: Distinct expression pattern of periostin splice variants in chondrocytes and ligament progenitor cells. FASEB J. 2019;33(7):8386-405. https://doi.org/10.1096/fj.201802281R.

24. Bonnet N, Gineyts E, Ammann P, Conway SJ, Garnero P, Ferrari S. Periostin deficiency increases bone damage and impairs injury response to fatigue loading in adult mice. PLoS One. 2013;8(10):e78347. https://doi.org/10.1371/ journal.pone.0078347.

25. Duchamp de Lageneste O, Julien A, Abou-Khalil R, Frangi G, Carvalho C, Cagnard N, Cordier C, Conway SJ, Colnot C. Periosteum contains skeletal stem cells with high bone regenerative potential controlled by Periostin. Nat Commun. 2018:9(1):773.

26. Yu L, Wang J, Liu K. Role of periostin in ECRS. Eur Arch Otorhinolaryngol. 2020. https://doi.org/10.1007/s00405-020-06369-x.

27. Nakazeki F, Nishiga M, Horie T, Nishi H, Nakashima Y, Baba O, Kuwabara Y, Nishino T, Nakao T, Ide Y, Koyama S, Kimura M, Tsuji S, Sowa N, Yoshida S, Conway SJ, Yanagita M, Kimura T, Ono K. Loss of periostin ameliorates adipose tissue inflammation and fibrosis in vivo. Sci Rep. 2018;8(1):8553. https://doi.org/10.1038/s41598-018-27009-9.

28. Idolazzi L, Ridolo E, Fassio A, Gatti D, Montagni M, Caminati M, Martignago I, Incorvaia C, Senna G. Periostin: the bone and beyond. Eur J Intern Med. 2017;38:12-6. https://doi.org/10.1016/j.ejim.2016.11.015

29. Ma HL, Blanchet TJ, Peluso D, Hopkins B, Morris EA, Glasson SS. Osteoarthritis severity is sex dependent in a surgical mouse model. Osteoarthr Cartil. 2007; 15(6):695-700. https://doi.org/10.1016/j.joca.2006.11.005.

30. Glasson SS, Blanchet TJ, Morris EA. The surgical destabilization of the medial meniscus (DMM) model of osteoarthritis in the 129/SvEv mouse. Osteoarthr Cartil. 2007;15(9):1061-9. https://doi.org/10.1016/j.joca.2007.03.006.

31. Chinzei N, Rai MF, Hashimoto S, Schmidt EJ, Takebe K, Cheverud JM, Sandell LJ. Evidence for genetic contribution to variation in posttraumatic osteoarthritis in mice. Arthritis Rheumatol. 2019:71(3):370-81. https://doi. org/10.1002/art.40730

32. Glasson SS, Chambers MG, Van Den Berg WB, Little CB. The OARSI histopathology initiative - recommendations for histological assessments of 
osteoarthritis in the mouse. Osteoarthr Cartil. 2010;18(Suppl 3):S17-23. https://doi.org/10.1016/j.joca.2010.05.025.

33. Lewis JS, Hembree WC, Furman BD, Tippets L, Cattel D, Huebner JL, Little D, DeFrate LE, Kraus VB, Guilak F, et al. Acute joint pathology and synovial inflammation is associated with increased intra-articular fracture severity in the mouse knee. Osteoarthr Cartil. 2011;19(7):864-73. https://doi.org/10.101 6/j.joca.2011.04.011.

34. Takebe K, Rai MF, Schmidt EJ, Sandell LJ. The chemokine receptor CCR5 plays a role in post-traumatic cartilage loss in mice, but does not affect synovium and bone. Osteoarthr Cartil. 2015;23(3):454-61. https://doi.org/1 0.1016/j.joca.2014.12.002.

35. Dempster DW, Compston JE, Drezner MK, Glorieux FH, Kanis JA, Malluche H, Meunier PJ, Ott SM, Recker RR, Parfitt AM. Standardized nomenclature, symbols, and units for bone histomorphometry: a 2012 update of the report of the ASBMR Histomorphometry Nomenclature Committee. J Bone Miner Res. 2013;28(1):2-17. https://doi.org/10.1002/jbmr.1805.

36. Duan X, Cai L, Schmidt EJ, Shen J, Tycksen ED, O'Keefe RJ, Cheverud JM, Rai MF. RNA-seq analysis of chondrocyte transcriptome reveals genetic heterogeneity in LG/J and SM/J murine strains. Osteoarthr Cartil. 2020;28(4): 516-27. https://doi.org/10.1016/j.joca.2020.01.001.

37. Dobin A, Davis CA, Schlesinger F, Drenkow J, Zaleski C, Jha S, Batut P, Chaisson M, Gingeras TR. STAR: ultrafast universal RNA-seq aligner. Bioinformatics. 2013; 29(1):15-21. https://doi.org/10.1093/bioinformatics/bts635.

38. Liao Y, Smyth GK, Shi W. featureCounts: an efficient general purpose program for assigning sequence reads to genomic features. Bioinformatics. 2014;30(7):923-30. https://doi.org/10.1093/bioinformatics/btt656.

39. Wang L, Wang S, Li W. RSeQC: quality control of RNA-seq experiments. Bioinformatics. 2012;28(16):2184-5. https://doi.org/10.1093/bioinformatics/bts356.

40. Robinson MD, McCarthy DJ, Smyth GK. edgeR: a bioconductor package for differential expression analysis of digital gene expression data. Bioinformatics. 2010;26(1):139-40. https://doi.org/10.1093/bioinformatics/btp616.

41. Ritchie ME, Phipson B, Wu D, Hu Y, Law CW, Shi W, Smyth GK. limma powers differential expression analyses for RNA-sequencing and microarray studies. Nucleic Acids Res. 2015;43(7):e47. https://doi.org/10.1093/nar/gkv007.

42. Liu R, Holik AZ, Su S, Jansz N, Chen K, Leong HS, Blewitt ME, Asselin-Labat ML, Smyth GK, Ritchie ME. Why weight? Modelling sample and observational level variability improves power in RNA-seq analyses. Nucleic Acids Res. 2015;43(15):e97. https://doi.org/10.1093/nar/gkv412.

43. Leek JT, Johnson WE, Parker HS, Jaffe AE, Storey JD. The sva package for removing batch effects and other unwanted variation in high-throughput experiments. Bioinformatics. 2012;28(6):882-3. https://doi.org/10.1093/ bioinformatics/bts034

44. Luo W, Friedman MS, Shedden K, Hankenson KD, Woolf PJ. GAGE: generally applicable gene set enrichment for pathway analysis. BMC Bioinformatics. 2009;10(1):161. https://doi.org/10.1186/1471-2105-10-161.

45. Zhao S, Guo Y, Sheng Q, Shyr Y. Advanced heat map and clustering analysis using heatmap3. Biomed Res Int. 2014;2014:986048.

46. Tajika Y, Moue T, Ishikawa S, Asano K, Okumo T, Takagi H, Hisamitsu T. Influence of periostin on synoviocytes in knee osteoarthritis. In Vivo. 2017; 31(1):69-77. https://doi.org/10.21873/invivo.11027.

47. Lee JH, Chun KJ, Kim HS, Kim SH, Han P, Jun Y, Lim D. Alteration patterns of trabecular bone microarchitectural characteristics induced by osteoarthritis over time. Clin Interv Aging. 2012;7:303-12.

48. Patel V, Issever AS, Burghardt A, Laib A, Ries M, Majumdar S. MicroCT evaluation of normal and osteoarthritic bone structure in human knee specimens. J Orthop Res. 2003;21(1):6-13. https://doi.org/10.1016/S0736-02 66(02)00093-1

49. Fang H, Huang L, Welch I, Norley C, Holdsworth DW, Beier F, Cai D. Early changes of articular cartilage and subchondral bone in the DMM mouse model of osteoarthritis. Sci Rep. 2018;8(1):2855. https:/doi.org/10.1038/s41598-018-21184-5.

50. Hashimoto S, Rai MF, Janiszak KL, Cheverud JM, Sandell LJ. Cartilage and bone changes during development of post-traumatic osteoarthritis in selected LGXSM recombinant inbred mice. Osteoarthr Cartil. 2012;20(6):56271. https://doi.org/10.1016/j.joca.2012.01.022.

51. Rai MF, Duan X, Quirk JD, Holguin N, Schmidt EJ, Chinzei N, Silva MJ, Sandell $\sqcup$. Post-traumatic osteoarthritis in mice following mechanical injury to the synovial joint. Sci Rep. 2017;7(1):45223. https://doi.org/10.1038/srep45223.

52. Glasson SS, Askew R, Sheppard B, Carito B, Blanchet T, Ma HL, Flannery CR, Peluso D, Kanki K, Yang Z, Majumdar MK, Morris EA. Deletion of active ADAMTS5 prevents cartilage degradation in a murine model of osteoarthritis. Nature. 2005;434(7033):644-8. https://doi.org/10.1038/na ture03369.

53. Han T, Mignatti $P$, Abramson SB, Attur M. Periostin interaction with discoidin domain receptor-1 (DDR1) promotes cartilage degeneration. PLoS One. 2020;15(4):e0231501. https://doi.org/10.1371/journal.pone.0231501.

54. Fan B, Liu X, Chen X, Xu W, Zhao H, Yang C, Zhang S. Periostin mediates condylar resorption via the NF-kappaB-ADAMTS5 pathway. Inflammation. 2020;43(2):455-65. https://doi.org/10.1007/s10753-019-01129-4.

55. Herault $Y$, Hraba-Renevey $S$, van der Hoeven F, Duboule D. Function of the Evx-2 gene in the morphogenesis of vertebrate limbs. EMBO J. 1996;15(23): 6727-38. https://doi.org/10.1002/j.1460-2075.1996.tb01062.x.

56. Agarwala KL, Ganesh S, Tsutsumi Y, Suzuki T, Amano K, Yamakawa K. Cloning and functional characterization of DSCAML1, a novel DSCAM-like cell adhesion molecule that mediates homophilic intercellular adhesion. Biochem Biophys Res Commun. 2001;285(3):760-72. https://doi.org/10.1006/ bbrc.2001.5214.

57. Tuure L, Pemmari A, Hamalainen M, Moilanen T, Moilanen E. Regulation of gene expression by MF63, a selective inhibitor of microsomal PGE synthase 1 (mPGES1) in human osteoarthritic chondrocytes. Br J Pharmacol. 2020; 177(18):4134-46. https://doi.org/10.1111/bph.15142.

58. Kaihara S, Bessho K, Okubo Y, Sonobe J, Komatsu Y, Miura M, Miyatake S, Nakao K, lizuka T. Over expression of bone morphogenetic protein-3b (BMP$3 b)$ using an adenoviral vector promote the osteoblastic differentiation in C2C12 cells and augment the bone formation induced by bone morphogenetic protein-2 (BMP-2) in rats. Life Sci. 2003;72(15):1683-93. https://doi.org/10.1016/S0024-3205(02)02477-3.

59. Lafont JE, Talma S, Hopfgarten C, Murphy CL. Hypoxia promotes the differentiated human articular chondrocyte phenotype through SOX9dependent and -independent pathways. J Biol Chem. 2008;283(8):4778-86. https://doi.org/10.1074/jbc.M707729200.

60. Wei Y, Shen X, Li L, Cao G, Cai X, Wang Y, Shen H. TM4SF1 inhibits apoptosis and promotes proliferation, migration and invasion in human gastric cancer cells. Oncol Lett. 2018;16(5):6081-8. https://doi.org/10.3892/ ol.2018.9411.

61. Padial-Molina M, Volk SL, Rios HF. Periostin increases migration and proliferation of human periodontal ligament fibroblasts challenged by tumor necrosis factor -alpha and Porphyromonas gingivalis lipopolysaccharides. J Periodontal Res. 2014;49(3):405-14. https://doi.org/1 $0.1111 /$ jre.12120.

62. Loeser RF. Aging and osteoarthritis. Curr Opin Rheumatol. 2011;23(5):492-6. https://doi.org/10.1097/BOR.0b013e3283494005.

63. Rai MF, Sandell LJ. Inflammatory mediators: tracing links between obesity and osteoarthritis. Crit Rev Eukaryot Gene Expr. 2011;21(2):131-42. https:// doi.org/10.1615/CritRevEukarGeneExpr.v21.i2.30.

64. Loeser RF. Aging and osteoarthritis: the role of chondrocyte senescence and aging changes in the cartilage matrix. Osteoarthr Cartil. 2009;17(8):9719. https://doi.org/10.1016/j.joca.2009.03.002.

65. Griffin TM, Guilak F. Why is obesity associated with osteoarthritis? Insights from mouse models of obesity. Biorheology. 2008;45(3-4):387-98. https:// doi.org/10.3233/BIR-2008-0485.

66. Thomas AC, Hubbard-Turner T, Wikstrom EA, Palmieri-Smith RM. Epidemiology of posttraumatic osteoarthritis. J Athl Train. 2017;52(6):491-6. https://doi.org/10.4085/1062-6050-51.5.08.

67. Punzi L, Galozzi P, Luisetto R, Favero M, Ramonda R, Oliviero F, Scanu A. Post-traumatic arthritis: overview on pathogenic mechanisms and role of inflammation. RMD Open. 2016;2(2):e000279. https://doi.org/10.1136/ rmdopen-2016-000279.

68. Brown TD, Johnston RC, Saltzman CL, Marsh JL, Buckwalter JA. Posttraumatic osteoarthritis: a first estimate of incidence, prevalence, and burden of disease. J Orthop Trauma. 2006;20(10):739-44. https://doi.org/10.1 097/01.bot.0000246468.80635.ef.

69. McNulty MA, Loeser RF, Davey C, Callahan MF, Ferguson CM, Carlson CS. Histopathology of naturally occurring and surgically induced osteoarthritis in mice. Osteoarthr Cartil. 2012;20(8):949-56. https://doi.org/10.1016/j.joca.2 012.05.001.

\section{Publisher's Note}

Springer Nature remains neutral with regard to jurisdictional claims in published maps and institutional affiliations. 